\title{
Equilibrium beach profile on sandy beach of the Mehdya coast of Morocco
}

\author{
Hind Azidane $^{1 *}$, Aïcha Benmohammad ${ }^{2}$, Boko Michel $^{3}$, and Mohamed El Bouhaddioui ${ }^{4}$ \\ ${ }^{1}$ Faculty of Sciences, Department of Geology, Ibn Tofail University, BP, 133 Kenitra, Morocco \\ ${ }^{2}$ Faculty of Sciences, Department of Geology, Ibn Tofail University, BP, 133 Kenitra, Morocco \\ ${ }^{3}$ Laboratory of Climatology, National University of Benin, Cotonou, Benin \\ ${ }^{4}$ National School of Mines, BP, 753, 14000 Agdal-Rabat, Morocco
}

\begin{abstract}
The world's coastlines are shaped by mean sea level, wave conditions and storm surge. Climate change driven variations in these environmental forcing's will inevitably have a profound effect on the coastal zone. They will result in unprecedented coastal recession, threatening billions of dollars worth of coastal developments and infrastructure. Coastal erosion is observed in some locations along Atlantic alluvial plain (Kenitra coastal (Morocco)) and is an important factor to consider for the coastal zone management. Therefore, for coastal recession estimates are obtained via the simple, deterministic method (Bruun rule) especially, that has been widely used over the last 50 years. It is in widespread contemporary use at a global scale both as a management tool and as a scientific concept. We investigated the potential erosion at the site and the result was very important. The result shows a severe erosion of the $21^{\text {st }}$ century.
\end{abstract}

\section{Introduction}

Coastal erosion caused by sea level rise and climate change is a serious problem for people all over the world [1]. As at least $70 \%$ of sandy beaches around the world are recessional. Therefore, the sandy beaches, the focus of much human economic and recreational activities, may not be stable in the long term [2] because they are not a permanent form on a coastal strip, rather, they are highly dynamic physiographic unit and continually adjust to subtle changes in hydrodynamic forcing, and the feedback between hydrodynamics and morphology [3]. The stable shape of a sandy coastline at a certain location is the result of natural and anthropogenic factors such as the rate of sediment, the rate of sediment removal and accumulation by wave action and currents, and sand mining [4]. The demand for recreational use of tourist beaches has increased substantially in recent decades, and associated with this increased human pressure. Recent studies have shown that many coastal zones around the world are threatened by coastline recession [5]. Unfortunately, there are many examples of unwanted changes to coastal areas following largescale construction of tourist infrastructure, i.e. in Morocco [6] .

For estimates the coastline recession, we used the Bruun rule [7]. This Rule provides a relationship between sea level rise and shoreline retreat and that, for more than five decades, has provided the engineering and scientific communities with a useful method of interpreting shoreline changes and designing beach stabilization projects, most notably beach nourishment projects.

* Corresponding author: azidane.hind2013@gmail.com

\subsection{Study area description}

Mehdya beach is located in North-West of Morocco near kenitra city. It is nearly $1 \mathrm{~km}$ long, and it is an embayed beach (See Figure 1) which is bounded by Atlantic continental shelf to the west and the subsiding Gharb plain to the east. The tide type is meso-diurnal [8] with a tidal range of $2.3 \mathrm{~m}$ on average, which can vary from 0.97 to $3.11 \mathrm{~m}$ during neap-spring periods, respectively [8]; and is composed of medium sand ranging between 200 and $370 \mu \mathrm{m}$ [9] with a gentle foreshore slope of $1-3 \%$ [10]. The beach is exposed to high-energy wave traveling roughly from the NW sector. These are generated by W-E tracking sub-polar, deep, low-pressure systems over the North Atlantic Ocean and are therefore strongly seasonally modulated. Substantially higher waves are observed during the December-March winter period [8]. It is hypothesized that significant wave heights can reach 7-9 m during severe storms [8]. 


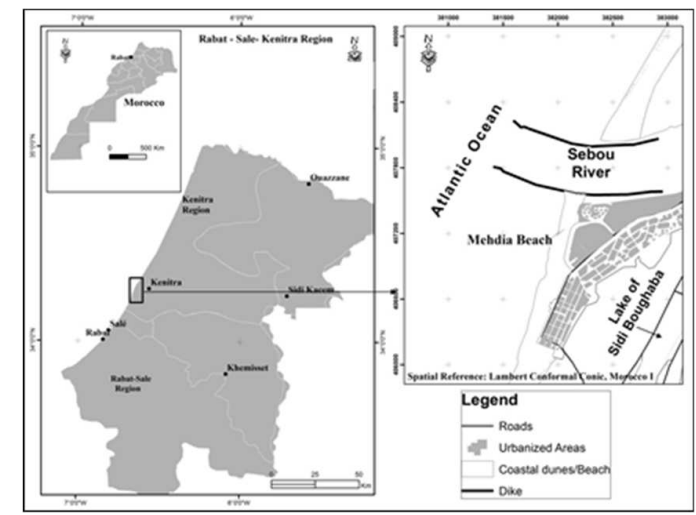

Fig. 1. Location map of the study area

Coastal currents, which have been observed to be highly variable and dependent on seasons and the local bathymetry, are of the order of 0.1-0.5 m/s [11] with generally northward and southward currents during flow and ebb, respectively.

Table 1. Sea level rise scenarios used in the study (based on data available from: IPCC. 2014)

\begin{tabular}{|c|c|c|}
\hline Scenarios & Year & $\begin{array}{c}\text { Sea Level } \\
\text { Rise [m] }\end{array}$ \\
\hline $\begin{array}{c}\text { IPCC- RCP } \\
2.6\end{array}$ & $2014-2065$ & 0.30 \\
\cline { 2 - 3 } & $2014-2100$ & 0.45 \\
\hline $\begin{array}{c}\text { IPCC- RCP } \\
8.5\end{array}$ & $204-2065$ & 0.40 \\
\cline { 2 - 3 } & $2014-2100$ & 0.74 \\
\hline
\end{tabular}

\section{Materials and methods}

\subsection{Topo-bathymetric of study area}

In Mehdya beach, the maritime area is characterized by relatively regular isobaths parallel to the coast. There is a bar (high depth) at about $550 \mathrm{~m}$ from the coast which here the depths go up locally to (-2/-3) $\mathrm{m} \mathrm{ZH})$ [12]

The 2 profiles have relatively similar slopes with offshore topside:

- A slope of $5.5 \%$ beyond $+4 \mathrm{~m} \mathrm{ZH}$ (dry beach);

- A slightly lower slope (4.7\%) at the foreshore (from +4 to $0 \mathrm{~m} \mathrm{ZH}$ );

- A very gentle slope $(0.8 \%)$ over about $200 \mathrm{~m}$ wide at $0 \mathrm{~m} \mathrm{ZH}$

- A slope of 3\% up to about $-6 \mathrm{~m} \mathrm{ZH}$ then beyond the breaking bar.

\subsection{Beach profiles}

The geomorphology of the coast reflects the nature of the coastal landforms with respect to their resistance to retreat [13]. Therefore, beach profiles are presented in order from $\mathrm{N}$ to along the Mehdya beach (around $4 \mathrm{~km}$ ), 4 full profiles were only measured in April 2016 and August 2015 (Figure 2). These profiles were well distributed and well localized in order to highlight the evolution and changes in the slope of the beach in space and time. For our fieldwork, a theodolite to measure the slope of the beach carried out topographic surveys.

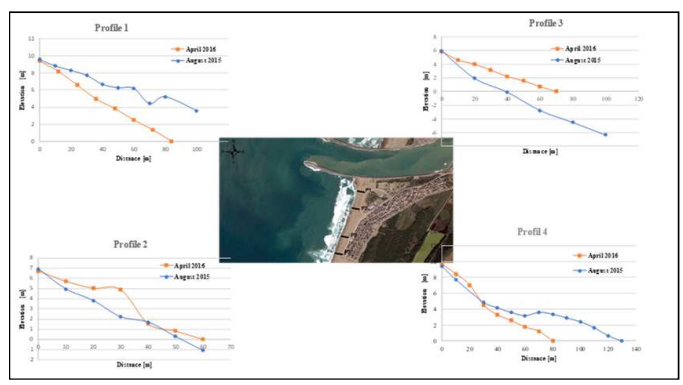

Fig. 2. Mehdya profiles

\subsection{Sea level rise}

The Intergovernmental Panel on Climate Change (2014) provides likely range and median values for four climate change scenarios (RCP 2.6, 4.5, 6.0 and 8.5). They corresponded with the projections of greenhouse gas emission scenarios. These scenarios indicate an increase in surface temperature during the next century [14]. In this study, the mean values of RCP2.6 and RCP8.5 scenarios, that are respectively the best and for worst conditions, have been adopted for the 2065 and 2100 projections (Table 1).

\subsection{Coastal erosion assessment}

The Bruun rule assume that all sand removed from the upper profile is deposited offshore as sea level rises, which relates the retreat of the coast $(\mathrm{R})$, to the elevation of sea level (S) by the relation of horizontal and vertical profiles within the active zone (Equation 1).

$$
R=S \frac{W_{*}}{h_{*}+B}
$$

Where:

$W_{*}$, is the width of the active zone or distance to the closing depth

$h *$ is the closing depth

$B$ is the berm height.

Calculation of closure depth (hc), the Hallermeier's equation (1981) [15] referred to in the Coastal Engineering Manual, 2002, was used (Equation 2).

$$
h_{c}=2.28 H_{e}-68.5\left(H_{e}{ }^{2} / g T_{e}{ }^{2}\right)
$$

Where: $H_{e}=\bar{H}+5.6 \sigma_{H}, \bar{H}$, is the significant wave height $\sigma_{H}$, is the standard deviation of significant wave height $T$, is the period of the effective wave and $g$, is the gravity acceleration.

The offshore significant wave height at Kenitra coast was compiled and resumed by [16]. As appreciate more than $90 \%$ of incoming waves have a significant wave 
height of $4 \mathrm{~m}$ with a predominant NW direction and a wave period of 15 second.

The Bruun rule was applied on the coast of Mehdya located on the left dike of Sebou estuary. The continental and marine geographic boundaries of the study area correspond to: (1) land side, with a length of $1 \mathrm{~km}$; with width of aerial beach is $200 \mathrm{~m}$ (Table 2); and with an area $\sim 240,000 \mathrm{~m}^{2}$.(2) sea side of the supposed boundary of sedimentary exchanges between the continental shelf and the coast $(10 \mathrm{~m})$.

Table 2.Morphological and sedimentological characteristics of Mehdya beach

\begin{tabular}{|c|c|c|c|c|c|}
\hline \multirow{2}{*}{ Beach } & \multirow{2}{*}{$\begin{array}{l}\text { Lengt } \\
\mathrm{h}[\mathrm{m}]\end{array}$} & \multirow{2}{*}{$\begin{array}{l}\text { Berm } \\
\text { of } \\
\text { height }[ \\
\mathrm{m}]\end{array}$} & \multicolumn{2}{|c|}{ Width [m] } & \multirow{2}{*}{$\begin{array}{c}\text { Sedime } \\
\text { nt }\end{array}$} \\
\hline & & & $\begin{array}{c}\text { Aeri } \\
\text { al } \\
\text { Beac } \\
\text { h }\end{array}$ & $\begin{array}{l}\text { Underwa } \\
\text { ter Beach }\end{array}$ & \\
\hline $\begin{array}{l}\text { Mehd } \\
\text { ya }\end{array}$ & 1000 & 4.17 & 200 & 1000 & $\begin{array}{l}\text { Fine } \\
\text { sand }\end{array}$ \\
\hline
\end{tabular}

The eroded volume of sand (in m3) at different depths was estimated by [17] :

$$
V=\Delta y \times\left(B+h_{*}\right)
$$

Where: $\Delta \mathrm{y}$ is the length of aerial beach and $\mathrm{h}^{*}$, is the closing depth; and $\mathrm{B}$ is the berm height

\section{Results and discussion}

A first observation of profiles 1 and 3 shows that they have a broad foreshore (around $120 \mathrm{~m}$ ) and a regularly concave transverse profile with a low slope (between 2 and $3 \%$ ). It must also be noted that the passage from the top to the bottom of the foreshore is often made without marked change of slope.

Profiles 2 and 4 have a broad slope with a steep slope which varies between $5 \%$ and $6 \%$ and often takes on the aspect of a fairly steep and less concave slope compared with the profile 1 . In profile 2 , the passage between the top and the bottom of the beach is made by a wellmarked slope break.

Mehdya beach is an erosive state due to seasonal evolution (The top of the beach has decreased about 20 $\mathrm{m}$ during the winter 2010). This is the result of pronounced decline north of the beach in recent years (Between 1997 and 2009) due to the realization of dredging operations at the level of the alluvial cone of the Sebou estuary which began in 2002. It is possible that dredging of the alluvial cone (Creation of a sediment trap by the realization of over funders) has resulted in reduced feeding of the Mehdia beach by the sediments expelled by the River (now trapped at the level of the alluvial cone).

To achieve the overall goal, geomorphology, coastal slope, rate of relative sea-level rise, mean tidal range, and mean wave height were determined as risk variables and the relevant regional data were collected.
The values of parameters used in the Bruun (1962) equation are presented for Mehdya Beach in Table 3.

Table 3. Values of the parameters used in the Bruun equation

\begin{tabular}{|c|c|c|c|}
\hline Beach & $\mathrm{W}^{*}[\mathrm{~m}]$ & $\mathrm{B}[\mathrm{m} \mathrm{ZH}]$ & $\mathrm{h} *[\mathrm{~m} \mathrm{ZH}]$ \\
\hline Mehdya & 650 & 4.17 & 8.6 \\
\hline
\end{tabular}

The coastal retreat $(R)$ is the percentages of areas lost are presented in Table 4 for RCP 2.6 scenario and for RCP 8.5.

Table 4. Land loss due to coastal erosion (R: retreat in $\mathrm{m})$

\begin{tabular}{|c|c|c|c|}
\hline Beach & Scenarios & Year & $\mathrm{R}$ (m/years) \\
\hline \multirow{5}{*}{ Mehdya } & & $2014-$ & 15.3 \\
& IPCC RCP & 2065 & \\
\cline { 2 - 4 } & 2.6 & $2014-$ & 22.9 \\
& & 2100 & \\
\cline { 2 - 4 } & & $2014-$ & 20.4 \\
& IPCC RCP & 2065 & \\
\cline { 2 - 4 } & 8.5 & $2014-$ & 37.7 \\
& & 2100 & \\
\hline
\end{tabular}

The areas of land that can be lost by coastal erosion have been defined by multiplying the horizontal retreatdefined by Bruun's rules-by the length of the beach, and this for the different hypotheses of each scenario $d$ of the sea level.

Near shore processes in the presence of relative sea level rise have been examined and show that in case of RCP 2.6 scenario, detailed calculations (Table 4) showed that with the hypothesis of SLR at 86 years, the Mehdya beach is most vulnerable than 51 years.

With the high climate change scenarios, this beach would semi completely disappear. This is expected to be completely lost and in the best scenarios, in only 11 years the sea will destroy the exisiting existent constructions in the first beach line. This situation will be worst and Mehdya Beach would be partially eroded.

\section{Conclusion}

Coastal processes are complex and vary with location and time, its occurs in Mehdya beach, in part, as a natural process of continuing change of the shoreline. The research allowed identifying an observable Bruun effect by the middle of the 21 st century in the case of beaches with gentle slopes, sandy sediment and for climate change scenarios RCP 2.6 and 8.5 only. Rather than predictions of future shoreline changes, our results can be viewed as an attempt to better understand theBruun rule validation. The erosion rates measured in this studywasimportant implying that the area is undergoing majorerosion. With the high climate change scenarios, this beach would semi completely disappear. This is expected to be completely lost and in the best scenarios, in only 11 years the sea will destroy the 
existent constructions in first beach line. Under this scenario, the integrity and physical stability of Mehdya beach are seriously threatened.Land losses from coastal erosion in the Mehdya range would be greater by 2100 . Thus, the beach would suffer a significant retreat and remain threatened by coastal erosion, whatever the hypothesis for the different scenarios of rising sea level; it would be doomed to disappear.

\section{References}

1. J. Yoshida, K. Udo, Y. Takeda, A. Mano. Framework for proper beach nourishment as adaptation to beach erosion due to sea level rise, Proceedings 13th International Coastal Symposium (Durban, South Africa), J.C. R., (2014)

2. A. Kwarteng, Y. Illenberger, W. K. Mclachlan, A. Sana. Beach erosion along Al Batinah coast, Sultanate of Oman, https://doi.org/10.1007/s12517015-2186-8, (2016)

3. J.R Hsu, C. Benedet, L. Klein, A.H.F Raabe. Appreciation of static bay beach concept for coastal management and protection. J.C. R. 24, 1 (2008)

4. E. Bird and N. Lewis. Beach Renourishment. Dordrecht, The Netherlands: Springer, 135p. Paperback with color illustrations, ISBN: 978-3-319-09727-5, (2015)

5. M. Gonzalez-Leija, I. Marino-Tapia, R. Silva, C. Enriquez, E. Mendoza. Morphodynamic evolution and sediment transport processes of Cancun Beach. J.C. R. 29, 5 (2013)

6. M. Snoussi. Impacts of sea-level rise on the Moroccan coastal zone: Quantifying coastal erosion and flooding in the Tangier Bay. https://doi.org/10.1016/j.geomorph.2006.07.043, (2009)

7. Bruun. (1962). Sea Level Rise as a Cause if Shore Erosion. Journal of Waterways and Harbors Division (ASCE) 1:116-130.

8. H. Azidane. Les risques d'érosion et de submersion côtiers du littoral de Kenitra Bouknadel : Mesures et modélisation. Thèse de doctorat, Université Ibn Tofail, Faculté des sciences, 164-165, (2019)

9. A. Benmohammadi, R. Griboulard, B. Zourarah. Hyperactive neotectonic near the South Rifian frontlifted late Quaternary lagunal deposit (Atlantic Morocco), Comptes Rendus Geosciences, 339, pp. 831-839, (2009)

10. J. Moussaid, A. fora, B. Zourarah, and M. Maanan. Using automatic computation to analyze the rate of shoreline change on the Kenitra coast, Morocco. Ocean Engineering, 102, 71-77, (2015)

11. M. Idrissi, , M. Ait Laamel, A. Hourimeche, M. Chagdali. Impact of the swell on the current morphological and sedimentary evolution of the coastal zone of Casablanca- Mohammedia (Morocco), J. Afr. Earth Sci. 39, (2004)
12. DPDPM. Etude d'expertise sédimentologique de la plage de Mehdia (Maroc). Rapport final, $\mathrm{n}^{\circ} 1712781,81 \mathrm{p},(2011)$

13. M.E Hereher. Assessment of South Sinai coastal vulnerability to climate change. J. C. R. 31, 6(2015)

14. IPCC. Fifth Assessment Report (AR5). Climate Change 2014: Mitigation of Climate Change Intergovernmental Panel on Climate Change. (2014)

15. R.J. Hallermeier. A profile zonation for seasonal sand beaches from wave climate. C. E. J., 4 (1981)

16. M. Hakkou, and B. Castelle. Wave climate and morphosedimentary characteristics of the Kenitra Bouknadel sandy coast, Morocco. (2011)

17. R.G. Dean. Beach Nourishment: Theory and Practice. World Scientifi c Publishing, 390 p. (2002) 